\title{
Rapid diagnostic test for the major mutation underlying Batten disease
}

Irma Järvelä, Hannah M Mitchison, Patricia B Munroe, Angela M O'Rawe, Sara E Mole, Ann-Christine Syvänen

\begin{abstract}
Batten disease is the most common progressive neurodegenerative disorder of childhood in western countries. A novel cDNA responsible for Batten disease has recently been identified. We have developed a rapid diagnostic solid phase minisequencing test to detect the major $1.02 \mathrm{~kb}$ deletion which is responsible for $81 \%$ of affected chromosomes in Batten disease worldwide. In Finland, $90 \%$ of Batten chromosomes carry the major deletion owing to the enrichment of the CLN3 gene in the isolated Finnish population. ( $f$ Med Genet 1996;33:1041-1042)
\end{abstract}

Key words: Batten disease; mutation; diagnostic test.

Batten disease (juvenile onset neuronal ceroid lipofuscinosis, Spielmeyer-Vogt) is the most common inherited neurodegenerative disorder of childhood with an incidence of 1:25000 in western countries. The clinical features include visual failure, seizures, psychomotor deterioration, and premature death. To date, the presence of vacuolated lymphocytes and retinal degeneration have been the most reliable diagnostic criteria. ${ }^{1}$ The gene, CLN3, underlying Batten disease is located on chromosome $16 \mathrm{p} 12.1 .^{2}$ The cDNA which is defective in Batten patients was recently identified, and it encodes a protein with unknown function. ${ }^{3}$ The major mutation underlying Batten disease is a $1.02 \mathrm{~kb}$ deletion which removes two exons, and it is carried by $81 \%$ of the affected chromosomes from 16 different populations analysed so far.

We have developed a solid phase minisequencing based diagnostic test to identify the major mutation. The method ${ }^{4}$ originally developed to detect point mutations was devised to detect the $1.02 \mathrm{~kb}$ deletion. The strategy for the method is described in fig 1. Three PCR primers (table 1) were designed according

Table 1 Primers

\begin{tabular}{lll}
\hline Name & Sequence $5^{\prime}$ to $3^{\prime *}$ & Position on the CLN3 gene \\
\hline 6081 & CATTCTGTCACCCTTAGAAGCC & nt 407-387 upstream of the $5^{\prime}$ deletion breakpoint \\
B-51332 & GGCTATCAGAGTCCAGATCCG & nt 51-31 downstream of the 3' deletion breakpoint \\
B-6302 & TGCACCCTTGATGTCTCTCC & nt 56-36 downstream of the 5' deletion breakpoint \\
6101 & TGACAGGGCGAGACTCCGTC & nt 20-1 upstream of the 5' deletion breakpoint
\end{tabular}

* The primers were synthesised on an Applied Biosystems 392 DNA Synthesiser. The 5' ends of the primers B-6302 and B-51332 were biotinylated during the synthesis.

to the previously determined genomic sequence of the CLN3 gene (H M Mitchison, personal communication). The result is expressed as the ratio $(R)$ of radioactivity incorporated in the reaction with the ${ }^{3} \mathrm{H}$-dCTP defining the mutated allele to that incorporated with the ${ }^{3} 3 \mathrm{H}-$ dTTP defining the normal allele (table 2). The genotype of each sample is unequivocally determined by the $R$ values, which fall into three distinct categories (tables 2 and 3 ). The $R$ values obtained were $>6$ for homozygotes for the mutation, $0.25-0.68$ for heterozygotes, and $<0.09$ for normal subjects (table 3 ). All patients $(n=37)$ who were known to carry the " 56 " haplotype (as defined by the microsatellite markers D16S299 and D16S298 closely linked to the CLN3 gene ${ }^{5}$ ) carried the $1.02 \mathrm{~kb}$ deletion. In addition, two sets of sibs homozygous for the haplotype " 46 " and " 66 ", respectively, and one patient with an unknown haplotype, were homozygous for the $1.02 \mathrm{~kb}$ deletion (table 4 ). The remaining patients showed $R$ values identical to the carriers, indicating that they carry the major mutation on one of their affected chromosomes and other, rarer mutations on the other chromosome (table 4). Our results show that $80 \%$ of the Finnish Batten families carry the major mutation in homozygous form with the remainder being compound heterozygotes. In all, $90 \%$ of the Finnish CLN3 chromosomes carry the major deletion.

The test will be informative for more than $80 \%$ of cases worldwide. ${ }^{3}$ The test also identifies carriers of the deletion and excludes healthy subjects as carriers of the disease. We have recently reported the prenatal diagnosis in a case of Batten disease, in which the $1.02 \mathrm{~kb}$ deletion was detected by PCR followed by size analysis of the products. ${ }^{6}$ The two methods were compared by analysing 25 samples, representing homozygous and heterozygous genotypes and concordant results were obtained in each case (data not shown). The minisequencing method represents an improvement compared to previously used size based iden-

(llich The Rayne Institute, University Street, London WC1E 6JJ, UK

H M Mitchison

B Munroe

A M O'Rawe

S E Mole

Correspondence to: Dr Järvelä.

Received 20 May 1996

Revised version accepted for publication 17 July 1996 
A

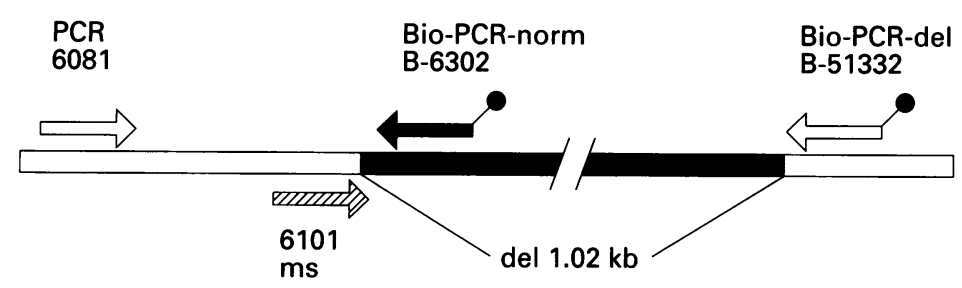

B

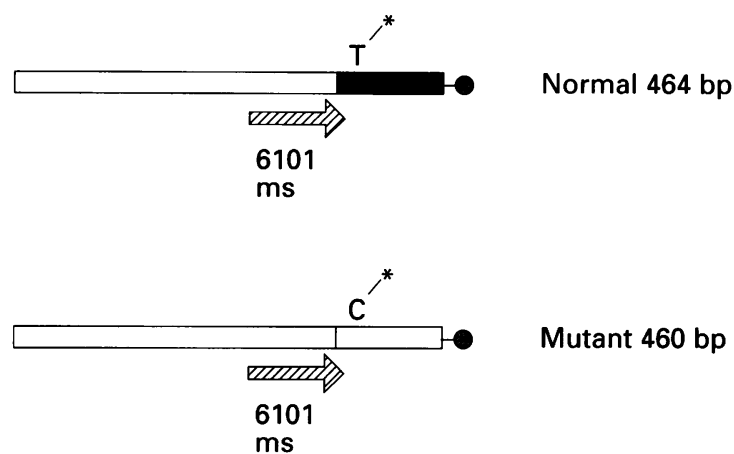

Figure 1 (A) Principle of the minisequencing test. The $5^{\prime}$ sense PCR primer (6081) was located upstream from the $1.02 \mathrm{~kb}$ deletion in intron 6 of the CLN3 gene. The biotinylated downstream primer for the normal allele $(B-6302)$ was located within the deletion, and the biotinylated downstream primer for the mutant allele (B-51332) was located immediately $3^{\prime}$ of the deletion. Approximately $25 \mathrm{ng}$ of DNA was amplified in a total volume of $100 \mu \mathrm{l}$ with the primer B-51332 at 0.2 $\mu$ molll, the primer B-6302 at $0.08 \mu$ molll, the non-biotinylated primer at $1 \mu$ molll, and the four dNTPs at $200 \mu \mathrm{mol} / \mathrm{l}$ concentration in $20 \mathrm{mmol} / \mathrm{l} \mathrm{Tris-} \mathrm{HCl}, \mathrm{pH} 9.3,1.5 \mathrm{mmol} / \mathrm{l} \mathrm{MgCl}, 15 \mathrm{mmoll} / \mathrm{N}\left(\mathrm{NH}_{4}\right) \mathrm{SO}_{2}$, $0.1 \%$ TritonX-100, and $0.01 \%$ gelatin using 1 unit of Dynazyme II DNA polymerase (Finnzymes Ltd, Espoo, Finland). The PCR was initiated by a "hot start", and 33 cycles of one minute at $94^{\circ} \mathrm{C}$, one minute at $56^{\circ} \mathrm{C}$, and one minute at $72^{\circ} \mathrm{C}$ were carried out. (B) PCR products obtained from the normal ( $464 \mathrm{bp}$ ) and mutant $(460 \mathrm{bp}$ ) alleles. Four $10 \mu \mathrm{l}$ aliquots of the PCR product from each sample and $40 \mu \mathrm{l}$ of $20 \mathrm{mmol} / \mathrm{l}$ sodium phosphate buffer, $\mathrm{pH} 7.5,0.15 \mathrm{molll} \mathrm{NaCl}$, and $0.1 \%$ Tween 20 were incubated at $37^{\circ} \mathrm{C}$ for 90 minutes in streptavidin coated microtitre wells with gentle shaking. The wells were then washed six times with 350 ll of $40 \mathrm{mmolll}$ Tris- $H C l, p H ~ 8.8,1$ mmolll EDTA, $50 \mathrm{mmol} / \mathrm{l} \mathrm{NaCl}$, and $0.1 \%$ Tween 20 , at $20^{\circ} \mathrm{C}$ using an automated microtitre plate washer. The wells were treated with $100 \mu \mathrm{l}$ of $50 \mathrm{mmolll} \mathrm{NaOH}$ for three to five minutes, and washed as above. Fifty microlitres of the minisequencing reaction mixture containing 10 pmol of the detection step primer 6101, $0.1 \mu \mathrm{Ci}$ of either ${ }^{3} \mathrm{H}-d C T P$ (TRK625, $71 \mathrm{Ci}$ mmol, Amersham) or ${ }^{3} \mathrm{H}-d T T P$ (TRK576, $134 \mathrm{Ci} / \mathrm{mmol}$ ) and 0.05 unit of Dynazyme II DNA polymerase in the PCR buffer were added to the wells, and the plates were incubated for 10 minutes at $50^{\circ} \mathrm{C}$. The wells were washed as above, and $70 \mu \mathrm{l}$ of

$50 \mathrm{mmolll} \mathrm{NaOH}$ were added to each well, and the plates were kept at $20^{\circ} \mathrm{C}$ for three to five minutes. The eluted radioacitivity was measured in a liquid scintillation counter.

Table 2 Example of the detection of the $1.02 \mathrm{~kb}$ deletion in the CLN3 gene by solid phase minisequencing

\begin{tabular}{|c|c|c|c|}
\hline \multirow[t]{2}{*}{ Sample type } & \multicolumn{2}{|c|}{ Incorporated radioactivity* } & \multirow{2}{*}{$\begin{array}{l}\text { Ratio } \\
{ }^{3} d C T P{ }^{3} d T T P\end{array}$} \\
\hline & ${ }^{3} H-d C T P$ & ${ }^{3} H-d T T P$ & \\
\hline $\begin{array}{l}\text { Homozygous del } 1.02 \mathrm{~kb} \\
\text { Heterozygous del } 1.02 \mathrm{~kb} \\
\text { Homozygous normal }\end{array}$ & $\begin{array}{r}2110 \\
1580 \\
92\end{array}$ & $\begin{array}{r}170 \\
3080 \\
3020\end{array}$ & $\begin{array}{l}12.4 \\
0.51 \\
0.030\end{array}$ \\
\hline
\end{tabular}

${ }^{*}$ Mean value of duplicate assays.

tification of the deletion mutation. Firstly, in the minisequencing test PCR products of a similar size are amplified from both alleles. This avoids the risk of preferential amplification of the significantly smaller allele which might result in the mistyping of a heterozygous sample as homozygous mutant. ${ }^{7}$ Moreover, an identical minisequencing test can be devised for the detection of point mutations in the CLN3 gene, and hence practically all mutations causing Batten disease can be screened for by the same test. Secondly, the minisequencing method
Table 3 Results of the solid phase minisequencing test of Finnish Batten patients homozygous for the major " 56 " haplotype*, obligate carriers of the " 56 " haplotype, and controls

\begin{tabular}{ll}
\hline Sample & $\begin{array}{l}\text { Ratio }^{3} \mathrm{H}-d C T P{ }^{3} H-d T T P \\
\text { (range of variation) }\end{array}$ \\
\hline Patients $(\mathrm{n}=37)$ & $6.0-31$ \\
Obligate carriers $(\mathrm{n}=50)$ & $0.25-0.68$ \\
Controls $(\mathrm{n}=50)$ & $0.029-0.090$ \\
\hline
\end{tabular}

* "56" haplotype formed by markers D16S299 and D16S298.

Table 4 Results of the minisequencing test of Finnish Batten patients carrying other than the major " 56 " haplotype

\begin{tabular}{lll}
\hline Haplotype & $\begin{array}{l}\text { Ratio } \\
{ }^{3} H-d C T P / \\
{ }^{3} H-d T T P^{*}\end{array}$ & Result \\
\hline $46 / 46$ & 13 & Homozygous for $1.02 \mathrm{del}$ \\
$46 / 46$ & 9.9 & Homozygous for $1.02 \mathrm{del}$ \\
$66 / 66$ & 8.8 & Homozygous for $1.02 \mathrm{del}$ \\
$66 / 66$ & 8.9 & Homozygous for $1.02 \mathrm{del}$ \\
$45 / 56$ & 0.34 & Heterozygous for $1.02 \mathrm{del}$ \\
$63 / 56$ & 0.31 & Heterozygous for $1.02 \mathrm{del}$ \\
$66 / 56$ & 0.31 & Heterozygous for $1.02 \mathrm{del}$ \\
$76 / 56$ & 0.44 & Heterozygous for $1.02 \mathrm{del}$ \\
$3 \mathrm{~kb}$ del/56 & 0.52 & Heterozygous for $1.02 \mathrm{~kb} \mathrm{del}$ \\
$\mathrm{ND}$ & 0.51 & Heterozygous for $1.02 \mathrm{del}$ \\
$\mathrm{ND}$ & 0.44 & Heterozygous for $1.02 \mathrm{del}$ \\
$\mathrm{ND}$ & 6.1 & Homozygous for $1.02 \mathrm{del}$ \\
\hline
\end{tabular}

* Mean values of duplicate assays.

$\mathrm{ND}=$ haplotype not determined.

comprises simple manipulations without gel electrophoretic separation steps and the results are obtained as objective numerical $\mathrm{cpm}$ values. Thus, the method can easily be automated facilitating computer assisted interpretation and data storage which are technical prerequisites for large scale mutation screening programmes. In prenatal diagnosis, any maternal contamination in a sample using this techique will be detected, as the $R$ value will fall outside the three distinct groups defining the genotypes. The test can be performed in one working day, and a large amount of the costs of demanding neurophysiological and electron microscopic investigations is avoided, which until recently have formed the diagnostic basis for Batten disease.

We thank Ms Anne Nyberg for technical assistance and Professo Leena Peltonen for encouragement with this work. This stud was supported by the Academy of Finland, the Paediatric Research Foundation (the Ulla Hjelt Fund), National Institute of Health (NINDA) grant NS28722, Medical Research Council (UK), and Wellcome Trust (UK). A M O'Rawe is a Wellcome Trust research fellow.

1 Santavuori P. Neuronal ceroid lipofuscinoses in childhood. Brain Dev 1988;10:80-3.

2 Gardiner RM, Sandford A, Deadman M, et al. Batten disease (Spielmeyer-Vogt; juvenile onset neuronal ceroid lipo-
fuscinosis) maps to human chromosome 16 . Genomics fuscinosis) maps

3 The International Batten Disease Consortium. Isolation of a novel gene underlying Batten disease, CLN3. Cell 1995;

4 Syvänen A-C, Ikonen E, Manninen T, et al. Convenient and quantitative determination of the frequency of a mutan allele using solid-phase minisequencing application to aspartylglucosaminuria in Finland. Genomics 1992;12:590-5. 5 Mitchison HM, O'Rawe AM, Taschner PEM, et al. Batten disease gene, $C L N 3$ : linkage disequilibrium mapping in the Finnish population and analysis of European haplotypes. Am 7 Hum Genet 1995;56:654-62.

6 Munroe PB, Rapola J, Mitchison HM, et al. Prenatal diagnosis of Batten disease. Lancet 1996;347:1014-15.

7 Walsh PC, Ehrlich HA, Higuchi R. Preferential PCR amplification of alleles: mechanisms and solutions. $P C R$ Methods and Applications 1992;1:241-50. 